Chapter 11

\title{
Cotton Germplasm Collection of Uzbekistan
}

\author{
Ibrokhim Y. Abdurakhmonov, Alisher Abdullaev, Zabardast Buriev, \\ Shukhrat Shermatov, Fahriddin N. Kushanov, Abdusalom Makamov, \\ Umid Shapulatov, Sharof S. Egamberdiev, Ilkhom B. Salakhutdinov, \\ Mirzakamol Ayubov, Mukhtor Darmanov, Azoda T. Adylova, \\ Sofiya M. Rizaeva, Fayzulla Abdullaev, Shadman Namazov, \\ Malohat Khalikova, Hakimjon Saydaliev, Viktor A. Avtonomov, \\ Marina Snamyan, Tillaboy K. Duiesenov, Jura Musaev, \\ Abdumavlyan A. Abdullaev and Abdusattor Abdukarimov
}

Additional information is available at the end of the chapter

http://dx.doi.org/10.5772/58590

\section{Introduction}

Uzbekistan, the northernmost cotton growing country, is the sixth largest cotton producer and the second largest cotton exporter in the world [1] with annual production of 0.85-1.0 million metric tons of fibre valued at US $\$ 0.9$ to 1.2 billion [1;2]. Cotton is grown in $\sim 30 \%$ of all lands available for crop cultivation in the country. Uzbekistan's cotton lint fibre yield was close to the world average of $753 \mathrm{~kg} / \mathrm{ha}$ in 2010/11 [4] and was estimated at $804 \mathrm{~kg} / \mathrm{ha}$ in 2012/13 and $812 \mathrm{~kg} / \mathrm{ha}$ in $2013 / 14[1 ; 5]$.

Cotton farming is affected by commonly observed cotton pathogens and pests, as well as major environmental stress factors (salinity, drought, heat, etc.) that greatly impacts the quality and yield characteristics of cotton cultivars. Therefore, the major objectives of the cotton breeding programs of Uzbekistan are the improvement of cotton fibre quality, lint yield, agronomic productivity, maturity, and resistance to various diseases, pests and abiotic stresses. During the past century of cotton production Uzbekistan prioritized and promoted cotton research and farming methods that resulted in increased cotton farming expertise, and the breeding of highly adapted, very-early maturing cotton cultivars suitable to be grown in the northern latitudes and arid zones $[6 ; 7 ; 8]$. This led to the development of a large number of cotton 
germplasm resources, which are being preserved and maintained for cotton genetics and breeding research that target current and future needs of the cotton improvement for different soil-climatic regions of Uzbekistan $[1 ; 2 ; 3 ; 8]$.

Aspects of Uzbekistan cotton germplasm resources including the content, distribution, descriptions, characterizations, utilization, genetic and molecular diversity, maintenance, and ongoing and prospective research previously have been highlighted in several documents [2; $3 ; 7 ; 8 ; 9 ; 10]$. In this chapter, we provide a detailed inventory of the Uzbekistan cotton germplasm collection, review previous reports and add updated information including the development and characterization of novel germplasm resources.

\section{History and development of Uzbekistan cotton collection}

The past century of cotton production in Uzbekistan has developed well-established cotton research programs and distinguished cotton scientists who initiated and devoted themselves to collecting important materials for cotton research. As highlighted in previous reports [3; 8] the cotton germplasm collection initiative was began by Drs. N. I. Vavilov and F. M. Mauer in 1930 in the former Soviet Union. Subsequently, Uzbekistan cotton germplasm founder and leader Dr. A. Abdullaev and his group expanded this initiative and established a collection of Uzbekistan germplasm materials through the (1) coordination of scientific efforts of continuous selection of cultivated cotton varieties, (2) continuation of collecting and preserving wild cotton species and landraces from centres of origin during many scientific expeditions, and (3) germplasm exchange worldwide.

According to Abdullaev et al. [8], several expeditions to Central Asia, Afghanistan, China, India, Turkey, Iran, Korea and Japan to obtain germplasm were made during 1920-1930, Dr. N. I. Vavilov, P. M. Jukovsky and Dr. F. M. Mauer, and in 1950s Dr. D. V. Ter-Avanesyan. In later periods from 1974 to 1998, Dr. A. Abdullaev visited to Mexico, Peru, China, India and Sri-Lanka, Australia and Pakistan and obtained germplasm. These historic scientific expeditions enriched Uzbekistan collection with Old World (Afro-Asian and Indian) diploid cottons (G. herbaceum and G. arboreum), and a number of wild, exotic and cultivated tetraploid and diploid cottons around the world [8].

The Uzbekistan collection has been periodically enriched as a result of germplasm exchanges with collections worldwide. In the most recent exchanges within the framework of USDAUzbekistan Cooperation programs, approximately 1000 G. hirsutum exotic and varietal accessions were exchanged with the US cotton germplasm collection [11; 12]. Annually, 100-120 cotton accessions from the collection of Uzbek Research Institute of Cotton Breeding and Seed Production (UzSRICBSP) are exchanged with world centres. During the period of 2001-2003, the Institute received 990 accessions from and sent 260 cotton accessions to the US cotton germplasm collection [7]. 


\section{Content of Uzbekistan cotton germplasm collection}

\subsection{Main collections}

The main cotton germplasm collections are being historically preserved at the research centres and institutions of the Academy of Sciences of Uzbekistan (ASUz), Ministry of Agriculture and Water Resources of Uzbekistan (MAWR), and the biology department of the National University (NU) of Uzbekistan. Table 1 summarizes and highlights the general content and description of cotton germplasm resources of these main collections. These collections maintain cultivars, wild and primitive, predomesticated landraces, hybrids breeding and genetic stocks, cytogenetic and mutant lines of widely cultivated allotetraploids(G. hirsutum and G. barbadense) representing the primary gene pool, and two cultivated Asian diploids (G. herbaceum and G. arboreum) representing the secondary gene pool. Although some redundancy of accessions maintained by collections could be possible and is a subject for future comparative inventory work, each collection has its own specificities and has been formed according to distinctive research efforts conducted by the scientists of these institutions for past decades.

\begin{tabular}{|c|c|c|c|c|c|c|}
\hline Germplasm type & G. hirsutum & G. barbadense & G. arboreum & G. herbaceum & $\begin{array}{c}\text { Other } \\
\text { species }\end{array}$ & Total \\
\hline \multicolumn{7}{|c|}{ Institute of Genetics and Plant Experimental Biology (IG\&PEB), Academy of Sciences of Uzbekistan (ASUz) } \\
\hline Cultivar/Line & 3735 & 827 & 736 & 338 & & 5636 \\
\hline Wild landraces & 402 & 6 & 25 & 11 & 45 & 489 \\
\hline Hybrids & 321 & 84 & 30 & 20 & 187 & 642 \\
\hline Unclassified & 445 & 53 & 66 & 178 & & 742 \\
\hline Total & 4903 & 970 & 857 & 547 & 232 & 7509 \\
\hline
\end{tabular}

Uzbek Scientific Research Institute of Cotton Breeding and Seed Production (UzSRICBSP), Ministry of Agriculture and Water Resources (MAWR), Republic of Uzbekistan

\begin{tabular}{lllllll}
\hline Cultivar/Line & 6597 & 908 & 200 & 161 & 28 & 7894 \\
\hline Wild landraces & 568 & 27 & 38 & 21 & 101 & 755 \\
\hline Hybrids & 1200 & 645 & 232 & 162 & 58 & 2297 \\
\hline Unclassified & 722 & 648 & 155 & 294 & 35 & 1854 \\
\hline Total & 9087 & 2228 & 625 & 638 & 222 & 12800 \\
\hline
\end{tabular}

Uzbek Research Institute of Plant Industry (UzRIPI), Ministry of Agriculture and Water Resources (MAWR), Republic of

\begin{tabular}{|c|c|c|c|c|c|c|}
\hline \multicolumn{7}{|c|}{ Uzbekistan } \\
\hline Cultivar/Line & 2105 & 64 & 44 & 55 & 314 & 2582 \\
\hline Wild landraces & 846 & 8 & 25 & 43 & 99 & 1021 \\
\hline Mutants & 1 & 1 & - & - & - & 2 \\
\hline Hybrids & 76 & 152 & - & - & 19 & 247 \\
\hline Unclassified & 1414 & 482 & 74 & 9 & 240 & 2219 \\
\hline Total & 4442 & 707 & 143 & 107 & 672 & 6071 \\
\hline
\end{tabular}




\begin{tabular}{|c|c|c|c|c|c|c|}
\hline Germplasm type & G. hirsutum & G. barbadense & G. arboreum & G. herbaceum & $\begin{array}{l}\text { Other } \\
\text { species }\end{array}$ & Total \\
\hline \multicolumn{7}{|c|}{ National University of Uzbekistan (NUUz) } \\
\hline $\begin{array}{l}\text { Genetic stocks of inbred } \\
\text { and RI lines }\end{array}$ & 771 & - & - & - & - & 771 \\
\hline \multicolumn{7}{|c|}{ Cytogenetic stocks/Mutants } \\
\hline Primary monosomics & 94 & - & - & - & - & 94 \\
\hline Tertiary monosomics & 22 & - & - & - & - & 22 \\
\hline Monotelodisomics & 20 & - & - & - & - & 20 \\
\hline Monoisodisomics & 4 & - & - & - & - & 4 \\
\hline Haploids & 4 & - & - & - & - & 4 \\
\hline Disynaptics & 31 & - & - & - & - & 31 \\
\hline Translocations & 235 & - & - & - & - & 235 \\
\hline & & & & & & 0 \\
\hline Total & 1181 & 0 & 0 & 0 & 0 & 1181 \\
\hline \multicolumn{7}{|c|}{ Centre of Genomics and Bioinformatics, ASUz, MAWR, and "UzCottonIndustry" association } \\
\hline \multicolumn{7}{|c|}{ Mapping panels } \\
\hline $\begin{array}{l}\text { Association mapping } \\
\text { individuals }\end{array}$ & 986 & 286 & - & - & - & 1272 \\
\hline $\begin{array}{l}\text { Nested association } \\
\text { mapping cross combination }\end{array}$ & $n^{20}$ & - & - & - & - & 20 \\
\hline \multicolumn{7}{|c|}{ Chromosome substitution line hybrids } \\
\hline $\mathrm{F}_{1}$ to $\mathrm{F}_{4}$ generation families & 260 & - & - & - & - & 260 \\
\hline CSUZ-RILs individuals & 301 & - & - & - & - & 301 \\
\hline \multicolumn{7}{|c|}{ Transformed lines } \\
\hline Tissue culture derived $\left(T_{1-6}\right)$ & 1444 & & & & & 1444 \\
\hline $\begin{array}{l}\text { Hybrids }\left(\mathrm{F}_{1-6} \text { and } \mathrm{BC}_{1-5}\right) \text { with } \\
\text { local cultivars }\end{array}$ & 1852 & & & & & 1852 \\
\hline \multicolumn{7}{|c|}{ MAS-derived germplasm } \\
\hline MAS $-F_{1-2}$ and $B C_{2-4}$ families & 551 & & & & 14 & 65 \\
\hline $\begin{array}{l}\text { MAS gene pyramiding } \\
\text { families }\end{array}$ & 24 & & & & & 24 \\
\hline Total & 4938 & 286 & 0 & 0 & 14 & 5238 \\
\hline Grand total & 24571 & 4190 & 1623 & 1292 & 937 & 32580 \\
\hline
\end{tabular}

Table 1. Summary of the content of Uzbekistan cotton germplasm collections

Cotton germplasm collection of the Institute of Genetics and Plant Experimental Biology (IG\&PEB) of the ASUz, founded and headed by academician and Prof. Abdumavlyan Abdullaev, preserves a total of 7,500 cotton accessions. The collection specifically aims to gather, maintain, and study wild cotton species, primitive, pre-domesticated landraces and domesticated genotypes from entire Gossypium genus. The IG\&PEB cotton germplasm 
collection, also referred to as "wild collection", was formed as a result of scientific expeditions to the centres of origin of Gossypium species and a 50 years of research efforts by IG\&PEB scientists and research programs. IG\&PEB cotton collection maintains more than 40 wild A-to G and K-genome Gossypium species [2;3;8] and targets the study of the taxonomy, phylogeny, evolution, hybridization compatibility, and introgression of wild germplasm for breeding purposes, all of which make the collection unique compared to others. The detailed description, content, geographic coverage and history of G. hirsutum and G. barbadense germplasm development in Uzbekistan were discussed by Abdullaev et al., 2013, where authors report the representation of 4 continents, $\sim 33$ geographic regions and $\sim 103$ countries by the IG\&PEB collection [8].There are a large number di-and tri-genomic hybrids and their diploid and allotetraploid progenies recovered from tedious sexual crosses within and/or between wild, primitive and domesticated genotypes within different gene pools [13; 14; Dr. Rizaeva, personal communication]. Some of examples such as tri-genomic hybrids were highlighted in previous reports $[14 ; 15]$.

MAWR has two distinctive cotton collections: one is preserved at the UzSRICBSP, another is in the Uzbek Research Institute of Plant Industry (UzRIPI), which was a Central Asian branch of All Union scientific-research institute after N.I. Vavilov. The UzSRICBSP collection preserves more than 12,000 cotton accessions from primary and secondary gene pools and refereed to as "breeding" germplasm resources that resulted from continuous breeding and selection efforts of the institute's scientists as well as cotton germplasm exchange efforts [16]. Geographically, this collection represents 107 countries of origin for cotton accessions [7]. The uniqueness of UzSRICBSP collection is its wide representation and coverage of cultivar germplasm developed and collected over the past century from worldwide breeding efforts. This collection also maintains synthetic tetraploid, pentaploid and octoploid hybrids [7; 16]. There are small differences in germplasm accession numbers reported here (Table 1) and by Ibragimov et al. [7]. However, our inventory is based on the latest information obtained from this collection (Dr. H. Saydaliev, a germplasm curator of the UzSRICBSP, personal communication).

The UzRIPI cotton collection has contents similar to those of the IG\&PEB collection and preserves a total of over 6,000 accessions (Table 1) from primary and secondary gene pools as well as accessions of other gene pools of wild species. Among all the collections, UzRIPI cotton collection is the richest resource for primitive, and pre-domesticated landrace stocks for all Gossypium gene pools in the country. However, there is a need to conduct comparative reinventory between UzRIPI and IG\&PEB collection to identify the distinctive versus redundant germplasm accessions. Because UZRIPI was the Central Asian branch of All Union scientificresearch institute after N.I. Vavilov some level of redundancies to Russian VIR collection is expected that requires future study.

The NU collection is tasked with maintaining of a total about 1200 germplasm resources that include 771 genetic stocks and recombinant inbred lines, formed during study of key cotton traits and mutations $[3 ; 17 ; 18]$. Additionally, the NU collection has a unique set of over 400 cytogenetics stocks primarily derived from radio-mutagenesis of a single genotype of $G$. 
hirsutum line L-458 [19; 20]. Readers can find detailed description of Uzbekistan's cytogenetic cotton collection in this book.

\subsection{Novel resources}

Efforts focused on genetic mapping of important traits, application of marker-assisted breeding as an aid for contemporary breeding, and the development of cotton tissue culturebased transgenomics programs and their integration into conventional cotton improvement efforts have resulted in the creation and collection of novel germplasm resources in Uzbekistan. These novel germplasm resources were developed in the past decade by scientists of Centre of Genomics and Bioinformatics (CGB), ASUz, MAWR, and "UzcottonIndustry association" within the framework of international collaborations and government funding $[1 ; 21 ; 22]$. The CGB collection with over 5,000 germplasm resources (Table 1) includes (i) panels of association mapping and nested-association mapping populations [22; 23; 24], (ii) hybrids and recombinant inbred lines $\left(\mathrm{F}_{1-4}\right)$ derived from the combination of sexual top crosses between 9 commercialized Uzbek cotton cultivars and 16 different chromosome substituted lines (CS-B) [25; 26; 27; 28; 29], (iii) germplasm resources developed through marker-assisted selection (MAS) programs that bear novel quantitative trait loci (QTL) loci mobilized from unique donors to the genetic background of commercial Uzbek cotton cultivars via molecular markers, and (iv) tissue culture-derived, genetically modified (GM) germplasm and their hybrids to local cultivars that bear RNA interference (RNAi), synthetic hairpin oligonucleotides, anti-sense, or overexpression genetic constructs for de novo characterized genes and sequence signatures in the CGB laboratories [1; $22 ; 30 ; 31 ; 32]$.

It is noteworthy to mention that association mapping individuals (Table 1) were selected from the IG\&PEB collection and re-grown at the Mexico Winter Nursery of USDA-ARS by Drs. Russel Kohel and John Yu, (cotton germplasm Unit of USDA-ARS at College Station,Texas) for phenotypic evaluations and seed increase. Increased seeds grown at the Mexican environment kindly were sent back to Uzbekistan by Dr. Richard Percy (USDA cotton germplasm curator) and currently backed-up at the CGB and IG\&PEB collections. Additionally, chromosome substituted (CS-B) lines were received within the frame of USDA-Uzbekistan Cooperation Programs, kindly provided by Dr. David Stelly (Texas A\&M University), Dr. Sukumar Saha and Dr. Johnie Jenkins, USDA-ARS, Starkville, Mississippi, and now are preserved in both CGB and IGPEB collections. CGB scientists in collaboration with USDA partners are developing CS-B specific chromosome substituted recombinant inbred lines (CSRILs) in the background of important Uzbekistan cultivars. Further, development of cotton tissue culture and trangenomics efforts [21], and the mobilization of useful genetic constructs into commercialized cultivars has created novel germplasm resources, useful for cotton improvement and helpful to address many problems associated with improving and boosting yield and quality [1; 22; 32]. 


\section{Storage, maintenance and funding}

The above-mentioned main collections and novel germplasm resources are stored and maintained in each institution and managed separately by its scientists. The IG\&PEB, UzSRICBSP, and NU collections are stored under room temperature conditions $\left(20-25^{\circ} \mathrm{C}\right)$ and there is no facility available for cold storage of germplasm accessions [3; 8]. In contrast, UzRIPI [33] and CGB collections are stored in short term (under $+4^{\circ} \mathrm{C}$ ) cold room facilities that were established as a result of government and international funding (in the case of UzRIPI, [33]. No long term cold storage $\left(-20\right.$ or $\left.-80^{\circ} \mathrm{C}\right)$ facilities, requiring attention and investment, are available for any of the germplasm collections in Uzbekistan, as highlighted by Campbell et al. [3] and Abdullaev et al. [8].

Germplasm accession seeds are preserved according to commonly practised procedures used over the decades of germplasm maintenance efforts in each collection. For instance, according to previous reports [8] germplasm seeds are ginned and put into paper bags with a label of catalogue number, accession name, year of collection and origin. Paper bags also contain "the weight of seeds (50 g or $100 \mathrm{~g}$ individual or total pick respectively") and "bags are stored in special metal boxes $(30 \times 11 \mathrm{~cm})$ and boxes are placed in wooden-cases" [8]. Other collections follow similar storage procedure with some modifications in types of storage boxes and variations in labelling of bags. Since 2003, after the reconstruction of the building for germplasm resources at UZRIPI, cotton germplasm seed have been stored in plastic containers [33].

Consequently, germplasm resources, in particular those without short term cold room facility, are scheduled for seed renewal every 8-10 years under forced self-pollination in the open field conditions [3]. Each organization has its own, but very similar protocols, schemes of planting, growing and evaluating germplasm (see [8] for detailed protocol for IG\&PEB cotton collection), government research grants and field extension stations with up to 8-10 staff working on germplasm maintenance. During a seed renewal year, accessions of re-grown germplasm are phenotypically evaluated for major agronomic and morpho-biological and fibre quality traits $[3 ; 8]$.

Germplasm evaluation records from each collection are maintained as a hard copy catalogue book that contains all descriptions about accessions (origin, year, collector, collected sites, seed renewal, etc), and data from the past 50 years of evaluations [e.g. 34] In UzRIPI, there is a "Unified Council for Mutual Economic Assistance (COMECON) list of descriptors for the species Gossypium L [35]. IG\&PEB has started using modified "Cotton descriptor" of International Plant Genetic Resource Institution [see below for detail description; 3; 8]. Moreover, data records on germplasm accession characteristics and description are being currently entered into electronic Microsoft database formats (personal communications with germplasm heads of all collections). All cotton collections also have their own greenhouse facilities to vegetatively maintain $[7 ; 8]$ wild and primitive accessions, unique multigenomic hybrids, mutants, and cytogenetics stocks as well as transformed and somatically regenerated lines. 
As reported by Campbell et al. [3], all germplasm related activities and maintenance of the Uzbekistan cotton collections are funded by the Committee for Coordination of Science and Technology Development under the Cabinet of Ministry of Uzbekistan, MAWR, and ASUz where funds are given as competitive research and "a unique facility" maintenance grants. Moreover, each institution receives international grants for projects that utilize the germplasm resources, and therefore, budget funding for germplasm related works [3].

\section{Sharing and exchange}

As highlighted in the recent reports by Campbell et al. [3] and Abdullaev et al. [8], all existing cotton germplasm resources, deposited and preserved in the country, are available for cotton researchers, breeders, and students who are conducting the cotton research. Written requests should be addressed to the directors of institutions, and should describe the purpose of the germplasm usage and specify the amount of seeds requested. Directors of institutions, with approval and on the responsibility of germplasm curators, grant the distribution of requested germplasm. If a specific germplasm with commercial interest is requested, a bi-lateral agreements are sought defining the condition of sharing that varies according institutions' internal regulations. All granted requests are registered in the germplasm exchange book of the collection.

Previously, germplasm requested by foreign institutions were officially sent under a standard "research purposes only" Material Transfer Agreement (MTA) and accompanied by proper phytosanitary certificates upon approval of the National Coordinator of Plant Genetic Resources (PGR) of Uzbekistan and responsible offices at the MAWR. Presently, any genetic and biological material sharing is granted by approval of Committee for Coordination of Science and Technology Development under the Cabinet of Ministry of Uzbekistan with "a research purpose only" MTA.

\section{Characterization and utilization of the collection}

Detailed evaluation, characterization, and cataloguing of germplasm accessions in the collections are very important to the utility of the collections by the local and world cotton research community interested in using 'candidate' accessions for breeding purposes. As mentioned above, during the periodic renewal of seed of germplasm accessions to maintain the collection, accessions are evaluated and characterized for the major characteristics and traits useful for both biodiversity estimates and cotton improvement. Each collection has its independent programs and objectives toward this goal; therefore, there was a need to develop a unified germplasm evaluation methodology and descriptors [11; 12]. 


\subsection{Cotton germplasm descriptor and database}

In UzRIPI, there is a computerized "CAC-DB" database for plant germplasm resources developed for Central Asian and Transcaucasian countries using Microsoft FoxPro [36; 37]. In this database, the principle information systems of the International Centre for Agricultural Research in the Dry Areas (ICARDA) and the N.I. Vavilov Research Institute of Plant Industry (VIR) is used. Major characteristics for the entire cotton collection of the UZRIPI as well as UzSRICBSP have been described in an electronic catalogue in Microsoft Excel (Dr. Fyzulla Abdullaev, germplasm specialist of the UzSRICBSP, personal communication).

Within the framwork of USDA-Uzbekistan cooperation programs, CGB scientists in collaboration with IG\&PEB colleagues and cotton germplasm Unit staff worked on updating the cotton cataloguing system. Scientists suggested the use of a modified version of the "Descriptor for Cotton" which was originally developed and approved by IPGRI in 1985 (http://www/ ipgri/cgiar.org). After considering recommendations from more recent descriptors for plant germplasm resources (e.g., Descriptor for Groundnuts-1992; and Descriptor for Pistachio-2002) and consulting with IG\&PEB germplasm curator and leaders (Dr. Abdumavlyan Abdullaev and Dr. Sofiya Rizaeva), some modifications were introduced to the "Descriptor for Cotton-1985" of IPGRI. In the modified descriptors, two categories: "characterization and preliminary evaluation" and "further characterization and evaluation" were combined into one category "characterization and evaluation" because of the lack of preliminary information for accessions that were brought from abroad to the IG\&PEB collection. New sub-categories, such as 1) cotton boll size, and 2) natural leaf defoliation properties were introduced; in "Susceptibility to biotic stresses" diseases and disease sources, specific to Uzbekistan, were introduced. At present, about 1,000 Upland germplasm accessions have been characterized for main agronomic, fibre quality properties and molecular diversity [12; 23; 24] using the modified “Descriptor for Cotton-1985" [Table 2; 8].

Further, 1000 G. hirsutum cotton accessions were selected from IG\&PEB cotton collection and evaluated for major morphological, agronomic and fibre quality traits in the Uzbekistan and Mexican growing environments in collaboration with Germplasm Unit of USDA-ARS at College Station, Texas, USA [12; 23; 24; 38]. Data from the evaluations was collected according to above mentioned descriptor. Consequently, pc-GRIN software package (used in creating US plant germplasm database) and Microsoft Access software packages were used to develop initial basic electronic database of IG\&PEB collection. This initial database contains most of information about accessions and morphological trait data, including fibre quality and yield properties as well as molecular-genetic data for each accession (such as in microsatellite marker genotypes, molecular diversity, etc.). There is ongoing effort to expand this database through adding additional germplasm accessions from periodic germplasm seed renewal evaluations. There is a need to apply the same procedure for all existing collections and coordinate future joint efforts toward this goal. 


\begin{tabular}{|c|c|c|c|c|}
\hline No & Trait & $\begin{array}{l}\text { Characteristic or short } \\
\text { description }\end{array}$ & Value & Notes \\
\hline \multirow{2}{*}{1} & \multirow{2}{*}{ SCIENTIFIC NAME } & \multirow{2}{*}{ Latin name } & & Name of genus, species, subspecies etc. (ex.: \\
\hline & & & & Gossypium hirsutum spp. mexicanum) \\
\hline 2 & ACCESSION NAME & Name of line or cultivar & & Ex.: TM-1, 3-79 \\
\hline 3 & ACCESSION NUMBER & $\begin{array}{l}\text { Number of accession in } \\
\text { collection catalogue }\end{array}$ & & Ex.: $1,2,3 \ldots$ \\
\hline 4 & ORIGIN & Place of sample origin & & Collection, author/scientist, country etc. \\
\hline 5 & YEAR & $\begin{array}{l}\text { Year of acceptance to } \\
\text { collection }\end{array}$ & & YYYY \\
\hline 6 & RENEWAL & Last time of seeds renewal & & DD.MM.YYYY \\
\hline \multirow{2}{*}{7} & \multirow{2}{*}{ HOMOGENIETY } & Not uniform & 0 & \multirow{2}{*}{$\begin{array}{l}\text { Homogeneity of cotton germplasm } \\
\text { population }\end{array}$} \\
\hline & & Uniform & 1 & \\
\hline \multirow{3}{*}{8} & \multirow{3}{*}{ GROW HABIT } & Prostrate & 3 & \multirow{3}{*}{ Growth of habit (Bush shape) } \\
\hline & & Compact & 5 & \\
\hline & & Erect & 7 & \\
\hline \multirow{4}{*}{9} & \multirow{4}{*}{ ANTOCYAN } & Weak & 0 & \multirow{4}{*}{-Colour of the plant in general } \\
\hline & & Middle & 1 & \\
\hline & & Strong & 2 & \\
\hline & & Not became brown & 3 & \\
\hline \multirow{5}{*}{10} & \multirow{5}{*}{ STEM HAIRINESS } & Naked & 1 & \multirow{5}{*}{ Hairiness of the plant stem } \\
\hline & & Very weak & 2 & \\
\hline & & Weak & 3 & \\
\hline & & Middle & 5 & \\
\hline & & Strong & 7 & \\
\hline 11 & LEAF HAIRINES & As above & & Hairiness of the leaves \\
\hline \multirow{4}{*}{12} & \multirow{4}{*}{ LEAFSHP } & Palmate(normal) & 1 & \multirow{4}{*}{-Leaf shape } \\
\hline & & Semi-digitate(semi-okra) & 2 & \\
\hline & & Digitate(okra) & 3 & \\
\hline & & Lanceolate(super okra) & 4 & \\
\hline$\overline{13}$ & LOBE NUMB & & Numeric & Number of leaf lobe \\
\hline 14 & EMERGENCE & & Numeric & Days to emergence of cotton seedlings \\
\hline 15 & SEEDENERGY \% & & Numeric & The energy required for seed germination \\
\hline 16 & SEEDTERM \% & $\begin{array}{l}\text { Seed energy in thermostat } \\
(\%)\end{array}$ & Numeric & $\begin{array}{l}\text { The energy required for seed germination in } \\
\text { thermostat }\end{array}$ \\
\hline 17 & BRHGHT (HS) & & Numeric & Height of the first fruit branch in $\mathrm{cm}$. \\
\hline \multirow{5}{*}{18} & \multirow{5}{*}{ BRANCHTYPE } & Branching Type & & \multirow{5}{*}{$\begin{array}{l}\text {-Distance of first sympodial fruit branch from } \\
\text {-first fruit brunch in } \mathrm{cm}\end{array}$} \\
\hline & & $0-5 \mathrm{~cm}$ & 1 & \\
\hline & & $5-10 \mathrm{~cm}$ & 2 & \\
\hline & & $10-15 \mathrm{~cm}$ & 3 & \\
\hline & & $15-20 \mathrm{~cm}$ & 4 & \\
\hline 19 & $\mathrm{HIEGHT}(\mathrm{cm})$ & & Numeric & Plant height in $\mathrm{cm}$. \\
\hline
\end{tabular}




\begin{tabular}{|c|c|c|c|c|}
\hline No & Trait & $\begin{array}{l}\text { Characteristic or short } \\
\text { description }\end{array}$ & Value & Notes \\
\hline 20 & MONO & & Numeric & Number of monopodia \\
\hline 21 & SYMP & & Numeric & Number of sympodia \\
\hline 22 & STEAMNODE & & Numeric & Number of total stem nodes \\
\hline \multirow{7}{*}{23} & \multirow{7}{*}{ PETAL colour } & White & 1 & \multirow{7}{*}{ Petal colour } \\
\hline & & Cream & 2 & \\
\hline & & Light yellow & 3 & \\
\hline & & Yellow & 4 & \\
\hline & & Lavender & 5 & \\
\hline & & Red & 6 & \\
\hline & & bicolour & 7 & \\
\hline \multirow{2}{*}{24} & \multirow{2}{*}{ PEATAL SPOT } & absent & 1 & \multirow{2}{*}{ Petal spot } \\
\hline & & present & 9 & \\
\hline \multirow{4}{*}{25} & \multirow{4}{*}{ POLLEN colour } & White & 1 & \multirow{4}{*}{ Pollen colour } \\
\hline & & Cream & 2 & \\
\hline & & Yellow & 3 & \\
\hline & & Purple & 4 & \\
\hline \multirow{4}{*}{26} & \multirow{4}{*}{ РHOTO } & Not photoperiodic & 0 & \multirow{4}{*}{ Sensitivity to day/night length } \\
\hline & & Slightly photoperiodic & 1 & \\
\hline & & Photoperiodic & 2 & \\
\hline & & Strictly photoperiodic & 3 & \\
\hline 27 & FLOWERING & & Numeric & Days to $50 \%$ of plants flowering \\
\hline 28 & OPENING & & Numeric & Days to $50 \%$ of bolls opening \\
\hline \multirow{3}{*}{29} & \multirow{3}{*}{ BOLL SH } & Round & 1 & \multirow{3}{*}{ Boll shape } \\
\hline & & Oval & 2 & \\
\hline & & Conical & 3 & \\
\hline \multirow{3}{*}{30} & \multirow{3}{*}{ BOLL OPEN } & Normal & 1 & \multirow{3}{*}{ Level of Boll opening } \\
\hline & & Intermediate & 2 & \\
\hline & & Strom-proof & 3 & \\
\hline 31 & BOLL NUM & & Numeric & Number of boll \\
\hline 32 & BOLL WEIGHT & Boll weight (g) & Numeric & Average weight in grams of a 10 boll sample \\
\hline 33 & LOCULES NUM & & Numeric & Locules per boll \\
\hline 34 & SEED WEIGHT & & Numeric & $\begin{array}{l}\text { Weight of } 100 \text { seeds in grams (could be } \\
\text { applied to cultivated plants only) }\end{array}$ \\
\hline \multirow{3}{*}{35} & \multirow{3}{*}{ SEED FUZZ } & Fuzzy & 1 & \multirow{3}{*}{ Fuzz grade (amount of fuzz on seeds) } \\
\hline & & Sparse fuzz & 2 & \\
\hline & & Naked seed & 3 & \\
\hline \multirow{4}{*}{36} & \multirow{4}{*}{ FUZZ colour } & White & 1 & \multirow{4}{*}{ Fuzz colour } \\
\hline & & Green & 2 & \\
\hline & & Grey & 3 & \\
\hline & & Brown (Tan) & 4 & \\
\hline 37 & LINT colour & White & 1 & Lint colour \\
\hline
\end{tabular}




\begin{tabular}{|c|c|c|c|c|}
\hline No & Trait & $\begin{array}{l}\text { Characteristic or short } \\
\text { description }\end{array}$ & Value & Notes \\
\hline & & Cream & 2 & \\
\hline & & Light brown & 3 & \\
\hline & & Brown & 4 & \\
\hline & & Green & 5 & \\
\hline 38 & fibre LENGHT & & Numeric & fibre length in millimeter \\
\hline 39 & T0 & fibre strength (g/tex) & Numeric & $\begin{array}{l}\text { The fibre strength of a bundle of fibres } \\
\text { measured on a Stelometre with the jaws } \\
\text { holding the fibre bundle tightly apprised. } \\
\text { Measured in grams force per tex. }\end{array}$ \\
\hline 40 & MIC & Micronaire & Numeric & $\begin{array}{l}\text { The fitness of the sample taken from the } \\
\text { ginned lint measured by the Micronaire and } \\
\text { expressed in standard curvilinear micronaire } \\
\text { units }\end{array}$ \\
\hline 41 & UI\% & & Numeric & fibre maturity in \% \\
\hline 42 & YELLOWNESS & fibre yellowness & Numeric & $\begin{array}{l}\text { Hunter's B value, a measure of increasing } \\
\text { yellowness of the cotton, taken with a } \\
\text { Nickerson-Hunter colourimeter }\end{array}$ \\
\hline 43 & REFLECT & Reflectance (RD) & Numeric & $\begin{array}{l}\text { A measure of the percentage of reflectance } \\
\text { on a Nickerson-Hunter colourimeter. The } \\
\text { higher the value the lighter the cotton. }\end{array}$ \\
\hline 44 & LINT & Lint (yield) percentage & Numeric & $\begin{array}{l}\text { The weight of lint ginned from sample of } \\
\text { seed cotton expressed as percentage of the } \\
\text { weight of seed cotton }\end{array}$ \\
\hline 45 & LINT INDEX & & Numeric & The weight of lint from 100 seed in gram \\
\hline 46 & ELO & $\begin{array}{l}\text { The percentage of fibre } \\
\text { elongation }\end{array}$ & Numeric & $\begin{array}{l}\text { The percentage of elongation at break of the } \\
\text { centre } 1 / 8 \text { each of the fibre bundle } \\
\text { measured for T1 strength on the Stelometer }\end{array}$ \\
\hline 47 & CGRD & & Numeric & colour grade of fibre \\
\hline 48 & AREA & Area of seed in \% & Numeric & Seed covered area with fibre \\
\hline \multirow{5}{*}{49} & \multirow{5}{*}{ DISEASE RES } & $\begin{array}{l}\text { Highly Resistant ( } \geq 86 \% \\
-100 \%)\end{array}$ & 1 & \multirow{5}{*}{$\begin{array}{l}\text {-Percentage of plants Resistant to pests/ } \\
\text {-insects or phytopathogen (fungi, bacteria, } \\
\text {-virus etc.) }\end{array}$} \\
\hline & & Resistant ( $\geq 76 \%-85 \%)$ & 2 & \\
\hline & & Moderate ( $\geq 51 \%-75 \%)$ & 3 & \\
\hline & & Susceptible ( $\geq 31 \%-50 \%)$ & 4 & \\
\hline & & Highly susceptible (1\%-30\%) & 5 & \\
\hline 50 & ENVRES & $\begin{array}{l}\text { Special resistance to } \\
\text { environmental conditions }\end{array}$ & As above & $\begin{array}{l}\text { Resistance to salt, drought, low water, } \\
\text { temperature etc. }\end{array}$ \\
\hline
\end{tabular}

Table 2. The descriptor developed for Uzbek cotton germplasm collection (Source: from Abdullaev et al., 2013) 


\subsection{Germplasm characterization and utilization}

Cotton germplasm Units of each collection work extensively on characterization of their own germplasm resources within the framework of various projects. IG\&PEB cotton germplasm Unit scientists, as mentioned above, investigate the evolution, taxonomy, phylogeny, hybridization compatibility, usage and introgression of wild germplasm. On the basis of investigations of the gene pools from IG\&PEB collection, Abdullaev et al. [39] updated the Mauer taxonomy system for Gossypium L. and highlighted new species discovered at the end of XX century in their updated taxonomy, which was unknown for Mauer [40]. Researchers also have created hybridization compatibility schemes and identified phylogenetic relations between different cotton species [41]. Accordingly, the IG\&PEB collection has developed a number of hybrids within and between different gene pools and cotton species. Cotton species and gene pools preserved in IG\&PEB collection were studied for morphological and anatomical characteristics in detail and an "Atlas of Gossypium L. genus" has been published [41].

Being a breeding collection of cultivated cottons in Uzbekistan, the UzSRICBSP researchers mainly use their collection to study genetics of various agronomic traits and disease resistance aspects of germplasm accessions during the variety development process [7; 16]. The NU collection, in particular the genetic stocks and cytogenetic stocks has been characterized in detail for the genetic traits [17] and cytogenetic aberrations [19; 20; 42]. The unique cytogenetic collection preserved at the NU also is being characterized using molecular markers and identification of chromosome specificities of the monosomics is in progress (Dr. Marina Sanamyan, personal communication).

Cotton germplasm resources were the foundation to develop highly adapted, disease resistant and superior agronomic quality cotton cultivars for Uzbekistan that were highlighted in a number of past reports $[2 ; 3 ; 6 ; 8 ; 10]$. In particular, forecasting the benefit of utilization of wild cotton germplasm accessions in conventional breeding of cotton in early 1960s by germplasm leaders, Drs. F. Mauer and A. Abdullaev [3; 8; 43] boosted the new variety development in Uzbekistan that provided timely responses to cotton production problems in the country. Over the past several decades, Uzbekistan breeders have developed more than 200 new cotton cultivars highly adapted [7] to the different soil-climatic regions of Uzbekistan, with high resistance characteristics to the major cotton diseases and pests, having high-yield and better fibre qualities $[6 ; 7 ; 8 ; 44]$. It is noteworthy to highlight here that the major accomplishment of Uzbekistan cotton breeders for the past century of efforts was the development of very earlymaturing and productive cotton cultivars with 105-120 days of vegetation period, which made cotton growing suitable and profitable in the northern latitudes like Uzbekistan. This was only possible because of the existence and efficient exploitation of cotton germplasm resources that should be highlighted and valued as Uzbekistan's cotton breeders greatest commitment.

Further, as highlighted in recent reports $[3 ; 8 ; 21]$ with the advances in cotton sciences and the development and application of modern molecular genetics tools and approaches for plant germplasm analysis [45], initial efforts by Uzbekistan scientist to characterize a selected global set of 1000 Gossypium hirsutum L. accessions from Uzbekistan cotton germplasm at molecular level have occured. This global set represented 37 cotton growing countries and 8 breeding ecotypes as well as wild landrace stocks. Using this selected set of global Upland germplasm 
resources, molecular genetic diversity, population diversification and strata, and the extent of linkage disequilibrium (LD) for the cotton genome were characterized $[10 ; 11 ; 12 ; 23 ; 24]$.

Efforts also identified several SSR markers associated with main fibre quality traits along with donor accessions, bearing "golden" QTLs useful for MAS programs [23; 24]. As a result, a successful MAS program has been established in Uzbekistan that facilitated to mobilize novel haplotypes of important fibre quality QTLs from donor accessions preserved in cotton germplasm collection to commercial cultivars. In that fibre trait-associated DNA markers were used as a tool to manipulate the transfer of QTLs during a genetic hybridization [38;46;47].

The MAS program, extensively utilized during past decade in Uzbekistan that involved several donor (germplasm accessions) and recipient (commercial cultivars) germplasm not only improved and developed novel MAS cultivars through mobilization of novel untapped loci but also created novel germplasm resources useful for cotton breeders and future cotton breeding [Table $1 ; 10 ; 38 ; 46 ; 47$ ]. Several first generation MAS-derived cultivars were developed and submitted for State Variety Testing Committee of Uzbekistan for future commercialization that are being field-trailed for improved agronomic and fibre qualities across the Uzbekistan regions. Moreover, as a ongoing effort, Uzbekistan researchers initiated a genepyramiding approach to combine major fibre quality traits into single genotype of several commercial Upland cotton cultivars of Uzbekistan using these effective molecular markers as a breeding tool and donor genotypes from cotton germplasm collections [38; 46; 47].

As a continuation of efforts to characterize cotton germplasm resources at the molecular level, about 300 G. barbadense (so called extra long staple fibre Pima cotton) accessions with wide geographic origin covering 17 countries worldwide were recently genotyped with SSR markers to estimate molecular diversity, phylogeny, population structure, and linkage disequilibrium level. These Pima cotton accessions were exchanged with USDA-ARS at Shafter, California, evaluated for major agronomic, morphological and fibre quality traits in the Uzbekistan or/and CA growing environments, and used for molecular mapping of fibre quality traits useful for MAS programs [8; Abdullaev et al., 2014 unpublished]

Use of cotton germplasm resources and their characterization at the molecular level further helped us to select the most diverse G. hirsutum accessions to create nested association mapping (NAM) panel. The creation of NAM populations is efficient approach to enhance power [48] of association mapping in cotton [10; 49]. Currently, a panel of $4000 \mathrm{~F}_{2: 3}$ generation NAM population individuals has been developed from genetic crosses between 20 most diverse $G$. hirsutum accessions and Uzbek cultivar Namangan-77, a genetic standard for G. hirsutum. NAM population individuals are also being genotyped with a large number of SSR markers and evaluated for major agronomic characteristics in different environments of Uzbekistan to conduct fine association mapping studies [22; Abdurakhmonov et al., 2014, unpublished].

Currently, genotyping of additional cotton germplasm accessions from major collections using widely available SSR markers is in progress that will help to characterize and organize the entire cotton germplasm resources of Uzbekistan. In perspective, we also aim to apply novel molecular tools such as SNP platforms and genotyping-by-sequencing (GBS) technologies to 
better characterize the selected cotton germplasm resources, AM and NAM panels that require additional funding, coordinated efforts and international collaborations.

\section{Conclusion}

Due to the importance of cotton production for the country and the historic expertise on cotton farming and production developed during the past century, Uzbekistan has prioritized and promoted the breeding programs, leading to a collection of one of the richest cotton germplasm resources in the world. Developed and maintained by several leading cotton research institutions in Uzbekistan, cotton germplasm collections preserve over 25,000 major cotton germplasm accessions of Gossypium species, wild, primitive, pre-domesticated landraces stocks, cultivar and breeding lines, mutants, genetic and cytogenetic stocks, and various types of within and between cotton gene pool hybrids. These resources were collected from the centres of origins of Gossypium species during scientific expeditions and through germplasm exchange with world germplasm centres, and developed by scientists and breeders of Uzbekistan for the past century. Consequently, these germplasm resources were the basis for the development of Uzbekistan's main commercial cultivars with early maturity and high productivity, making cotton profitable in the northernmost cotton growing country. This greatest achievement and commitment of cotton breeders timely responded and solved many past and current problems of cotton production as well as it will help to sustain the cotton production in Uzbekistan in the future.

Although each cotton collection has its own specific goals and objectives for preserved materials, there is a huge need for conducting joint re-inventory for clarification of redundancies between some of collections. There is a need for building short-term and long term cold storage rooms for all collections available in the country to better preserve the collection for future generations and cotton production. Moreover, although initial efforts have been made, coordinated efforts are needed to create a unified electronic database to systematize the germplasm records for all collections that will help for better utilization of the accessions in the breeding programs.

There are over 5,000 novel germplasm resources that were developed for past decade of collaborative efforts on molecular genetic characterization of cotton germplasm resources and establishment of modern MAS and GM programs. The modern cotton genomics and bioinformatics programs in combination with conventional cotton breeding efforts will further enhance the characterization and utilization as well as efficient documentation and systematization of the germplasm resources in Uzbekistan.

\section{Acknowledgements}

We thank the Uzbekistan government for continual funding support for cotton germplasm collections and research. We acknowledge the Office of International Research Programs 
(OIRP) of the United States Department of Agriculture (USDA) and USA partner laboratories for the financial support of cotton germplasm related works through project P120/P120a.

\section{Author details}

Ibrokhim Y. Abdurakhmonov ${ }^{1}$, Alisher Abdullaev ${ }^{1}$, Zabardast Buriev ${ }^{1}$, Shukhrat Shermatov ${ }^{1}$, Fahriddin N. Kushanov ${ }^{1}$, Abdusalom Makamov ${ }^{1}$, Umid Shapulatov ${ }^{1}$, Sharof S. Egamberdiev', Ilkhom B. Salakhutdinov ${ }^{1}$, Mirzakamol Ayubov ${ }^{1}$, Mukhtor Darmanov ${ }^{1}$, Azoda T. Adylova ${ }^{1}$, Sofiya M. Rizaeva ${ }^{2}$, Fayzulla Abdullaev ${ }^{2,4}$, Shadman Namazov ${ }^{3}$, Malohat Khalikova ${ }^{3}$, Hakimjon Saydaliev ${ }^{3}$, Viktor A. Avtonomov ${ }^{3}$, Marina Snamyan $^{4}$, Tillaboy K. Duiesenov ${ }^{5}$, Jura Musaev ${ }^{4}$, Abdumavlyan A. Abdullaev² and Abdusattor Abdukarimov ${ }^{1}$

1 Centre of Genomics and Bioinformatics, Academy of Sciences of Uzbekistan, Ministry of Agriculture and Water Resources of Uzbekistan, and "UzCottonIndustry" association, Tashkent, Uzbekistan

2 Cotton Germplasm Unit, Institute of Genetics and Plant Experimental Biology, Academy of Sciences of Uzbekistan, Tashkent, Uzbekistan

3 Uzbek Scientific Research Institute of Cotton Breeding and Seed Production, Ministry of Agriculture and Water Resources of Uzbekistan, Tashkent, Uzbekistan

4 Department of Biology, National University of Uzbekistan, Uzbekistan

5 Uzbek Research Institute of Plant Industry, Ministry of Agriculture and Water Resources, Uzbekistan

\section{References}

[1] Abdurakhmonov IY. Role of genomic studies in boosting yield. In: Overcoming of no-growth in yield, Papers presented in fifth technical seminar, 72nd Plenary meeting of International Cotton Advisory Board (ICAC), Cartagena: Columbia; September 29-October 4, 2013, (Available at: https://www.icac.org/cotton_info/publications/ tech_seminar/pub_tech_seminar/tis2013; verified on February 10, 2014).

[2] Abdurakhmonov IY. Exploiting genetic diversity. In: Ethridge D (eds): Plenary Presentations and Papers: Proceedings of World Cotton Research Conference-4; Sept 10-14, 2007, Lubbock, TX USA.

[3] Campbell BT, Saha S, Percy R, Frelichowski J, Jenkins JN, Park W, Mayee CD, Gotmare V, Dessauw D, Gband M, Du X, Jia Y, Constable G, Dillon S, Abdurakhmonov IY et al. Status of global cotton germplasm resources. Crop Sci 2010; 50: 1161-1179. 
[4] Cotton Fact Sheet, ICAC. 2011. (available at http://www.icac.org/econ_stats/country_fact_sheets/fact_sheet_uzbekistan_2011.pdf, verified on February 10, 2014).

[5] Cotton: World Statistics. 2009. Bulletin of International Cotton Advisory Committee (ICAC). Washington D.C., USA.

[6] Abdukarimov A, Djataev S, Abdurakhmonov IY. Cotton Research in Uzbekistan: Elite varieties and future of cotton breeding: Proceedings of WCRC-3, 2003, South Africa.

[7] Ibragimov PS, Avtonomov VA, Amanturdiev AB, Namazov SE, Zaurov DE, Molnar TJ, Eisenman SW, Orton TJ, Funk CR, Percival J, Edward A. Uzbek Scientific Research Institute of Cotton Breeding and Seed Production: Breeding and germplasm resources. J. Cotton Sci 2008; 12:62-72.

[8] Abdullaev A, Abdullaev AA, Salakhutdinov, Rizaeva S, Kuryazov Z, Ernazarova D, Abdurakhmonov IY. Cotton germplasm collection of Uzbekistan. In: Egamberdieva D, Abdurakhmonov I (eds). Cotton Research in Uzbekistan. Asian and Australasian Journal of Plant Science and Biotechnology 7 (Special Issue 2) 2013; 1-15.

[9] Chen ZJ, Scheffler BE, Dennis E, Triplett BA, Zhang T, Guo W et al. Toward sequencing cotton (Gossypium) genomes. Plant Physiol. 2007; 145:1303-1310.

[10] Abdurakhmonov IY, Buriev ZT, Shermatov SE, Abdullaev AA, Urmonov HU, Kushanov FN, Egamberdiev SS, Shapulatov UM, Abdukarimov AA, Sukumar S, Jenkins JN, Kohel RJ, Yu JZ, Pepper AE, Kumpatala SP, Ulloa M. Genetic diversity of Gossypium genus.: M. Caliskan (eds). Plant Genetic Diversity. Croatia: Intech; 2012a p313-338.

[11] Abdurakhmonov IY, Abdullaev A. Rizaeva S, Buriev Z, Adylova A, Abdukarimov A, Saha S, Kohel R, Yu J, Pepper A. Evaluation of G. hirsutum exotic accessions from Uzbek cotton germplasm collection for further molecular mapping purposes: Cotton Beltwide conference: Proceedings, 2004, San Antonio, Texas, USA.

[12] Abdurakhmonov IY, Buriev ZT, Salakhuddinov IB, Rizaeva SM, Adylova AT, Shermatov SE, Abdukarimov A, Kohel RJ, Yu JZ, Pepper AE, Saha S, Jenkins JN. Characterization of G. hirsutum wild and variety accessions from Uzbek Cotton Germplasm collection for morphological and fibre quality traits and database development: Cotton Beltwide Conference, Jan. 3-6, 2006, San Antonio, Texas, USA.

[13] Rizaeva SM. Interspecific hybridization of cotton and development of new cotton donor accessions (in the example of New World cottons). PhD thesis. Institute of Plant Experimental Biology of the Academy of Sciences of Uzbekistan, 1996.

[14] Rizaeva SM, Abdullaev AA, Klyat VP, Arslonov DM, Kuryazov ZB. Creation of donors with naturally early leaf defoliation. Uzbek Biol. Journal 2001; 4:65-70.

[15] Abdurakhmonov IY, Abdullaev AA, Saha S, Buriev ZT, Arslanov D, Kuryazov Z, Mavlonov GT, Rizaeva SM, Reddy UK, Jenkins JN, Abdullaev A, Abdukarimov A. 
Simple sequence repeat marker associated with a natural leaf defoliation trait in tetraploid cotton. Journal of Heredity 2005; 96:644-653.

[16] Saydaliev H. World cotton germplasm collection of Uzbek Research Institute of Cotton Breeding and Seed Production. Uzbek biology Journal 2006; 4:79-82 (in Russian).

[17] Musaev JA, Abzalov MF, Almatov A, Sanamyan MF, Gubanova N, Nadjimov U. Cotton genetics and genetic collection of isogenic, monosomic and translocation lines. Bulletins SCST of the republic of Uzbekistan 1997; 28-39.

[18] Abdurakhmonov IY, Buriev ZT, Saha S, Pepper AE, Musaev JA, Almatov A, Shermatov SE, Kushanov FN, Mavlonov GT, Reddy UK, Yu JZ, Jenkins JN, Kohel RJ, Abdukarimov A. Microsatellite markers associated with lint percentage trait in cotton, Gossypium hirsutum. Euphytica 2007; 156: 141-156.

[19] Sanamyan MF, Petlyakova JE, Sharipova EA, Abdurakhmonov IY. Morphological characteristics and identification of new monosomic stocks for cotton (Gossypium hirsutum L.). Advances in Bioscience and Biotechnology 2010; 1: 372-383.

[20] Sanamyan MF, Petlyakova JE, Sharipova EA, Abdurakhmonov IY. 2011. Cytogenetic Characteristics of New Monosomic Stocks of Cotton (Gossypium hirsutum L.). Genetics Research International 2011; (2011): 27364.

[21] Abdurakhmonov IY, Buriev Z, Shermatov S, Abdullaev A, Kushanov F, Abdukarimov A, Saha S, Jenkins J, Yu J, Kohel R, Percy R, Ulloa U, Stelly D, Pepper A. Cotton genomics and transgenomics in Uzbekistan: Proceedings of the International Cotton Genome Initiative, 2012b, Conference.

[22] Abdurakhmonov IY, Shapulatov UM, Shermatov SE, Buriev ZT, Abdullaev AA, Kushanov FN, Egamberdiev SS, Salahutdinov IB, Ubaydullaeva HA, Makamov AH, Darmanov MM, Ayubov MS, Norov TM, Tulanov AA, Mavlonov GT, Abdukarimov A. Achievements and perspectives of cotton "omics" in Uzbekistan: Proceedings of the International Cotton conference Bremen, March 19-21, 2014, Bremen, Germany.

[23] Abdurakhmonov IY, Kohel RJ, Yu JZ, Pepper AE, Abdullaev AA, Kushanov FN, Salakhutdinov IB, Buriev ZT, Saha S, Scheffler BE, Jenkins JN, Abdukarimov A. Molecular diversity and association mapping of fibre quality traits in exotic G. hirsutum L. germplasm. Genomics 2008; 92:478-87.

[24] Abdurakhmonov IY, Saha S, Jenkins JN, Buriev ZT, Shermatov SE, Scheffler BE, Pepper AE, Yu JZ, Kohel RJ, Abdukarimov A. Linkage disequilibrium based association mapping of fibre quality traits in G. hirsutum L. variety germplasm. Genetica 2009; 136:401-17.

[25] Stelly D, Saha S, Raska D, Jenkins J, McCarty J, Gutierrez O. Registration of 17 Upland (Gossypium hirsutum) germplasm lines disomic for different G. barbadense chromosome or arm substitutions. Crop Science 2005; 45: 6:2663-2665. 
[26] Saha S, Wu J, Jenkins J, McCarty J, Stelly D, Percy R, Raska D, and Gutierrez O. Effect of chromosome substitutions from Gossypium barbadense L. 3-79 into G. hirsutum L. TM-1 on agronomic and fibre traits. Journal of Cotton Science 2004; 8:162-169.

[27] Saha S, Stelly DM, Raska DA, Wu J, Jenkins JN, McCarty JC, Makamov A, Gotmare V, Abdurakhmonov IY, Campbell BT. Chromosome substitution lines: concept, development and utilization in the genetic improvement of Upland cotton, Plant Breeding, Ibrokhim Y. Abdurakhmonov (Ed.), Croatia: InTech; 2012.

[28] Jenkins J, Wu J, McCarty J, Saha S, Gutierrez O, Hayes R, Stelly D. Genetic effects of thirteen Gossypium barbadense L. chromosome substitution lines with Upland cotton cultivars: I. Yield and yield component. Crop Science 2006; 46:1169-1178.

[29] Jenkins J, Wu J, McCarty J, Saha S, Gutierrez O, Hayes R, Stelly D. Genetic effects of thirteen Gossypium barbadense L. chromosome substitution lines in topcrosses with Upland cotton cultivars: II fibre quality traits. Crop Science 2007; 47:561-570.

[30] Abdurakhmonov IY, Buriev ZT, Logan-Young CJ, Abdukarimov A, Pepper AE. Duplication, divergence and persistence in the phytochrome photoreceptor gene family of cottons (Gossypium spp.). BMC Plant Biol 2010; 10:119.

[31] Abdukarimov A, Abdurakhmonov IY, Buriev ZT, Bozorov TA. Small interfering RNA (siRNA) for knocking down gene expression in plant cells. Uzbekistan patent IAP 04300. Official bulletins of State Patents \#2-6, 2011.

[32] Abdurakhmonov IY, Buriev ZT, Saha S, Jenkins JN, Abdukarimov A, Pepper AE. Cotton PHYA1 RNAi enhances major fibre quality and agronomic traits of cotton (Gossypium hirsutum L). Nature Communications 2013; 5: 3062.

[33] Mavlyanova RF, Abdullaev FKh, Khodjiev P, Zaurov DE, Molhar TJ, Goffreda JC, Orton TJ, Funk CR. Plant Genetic Resources and Scientific Activities of the Uzbek Scientific Research Institute of Plant Industry. J Hort Science 2005; 40 (1):10-14.

[34] Muratov UH, Tadjibaev T, Alikhodjaev SS, Munasov K. Catalog of cotton cultivars. Tashkent: University Press; 1992. (in Russian).

[35] Lemishev N, Atlanov A, Podolnaya L, Korneychuk B. Unified Council for Mutual Economic Assistance (COMECON) list of descriptors for the species Gossypium L. Leningrad: VIR; 1989.

[36] Abdullaev FK. Information Technology Use for Documentation of Genepool in Uzbekistan.Genetic Resources of Cultivated Plants in XXI Century: Current Status, Problems, Perspectives: Abstracts of II Vavilov International Conference.-26-30 November 2007. St.Petersburg. pg. 669-670. (in Russian).

[37] Abdullaev FK. Management of Plant Genetic Resources by the Information Technology Base. Soil-Water Journal. 2013, 2: 2 (2). 
[38] Abdurakhmonov IY. Understanding and utilization of molecular diversity in cotton genome: TWAS Prize 2010 lecture, 22nd General meeting of TWAS, November 20-23, 2011, Trieste, Italy.

[39] Abdullaev A, Klyat VP, Rizaeva SM, Abdullaev AA, Abdurakhmonov IY. Cotton germplasm collection and an updated taxonomy of Gossypium L. 4th World Cotton Research Conference: Abstracts of World Cotton Research Conference-4; Sept 10-14, 2007, Lubbock, TX USA.

[40] Mauer FM. Origin and taxonomy of cotton. In Cotton. Academy of Sciences of USSR: Tashkent; 1954. (in Russian).

[41] Abdullaev AA, Dariev AC, Omelchenko MV, Klyat VP, Rizaeva CM, Saydaliev H, Khalikova MB.. Atlas of Gossypium L. genus. Tashkent: Fan; 2010.

[42] Sanamyan MF, Rakhmatullina EM. Cytogenetic analysis of translocations in cotton. Plant Breed 2003; 122 (6): 511-516.

[43] Abdullaev, AA, Klyat VP, Rizaeva SM. Cotton introduction in Uzbekistan-history and perspectives of using of plant introduction: problems and perspectives: Proceedings of $4^{\text {th }}$ National scientific-applied conference; July 3-4, 2009; Tashkent Uzbekistan. (in Russian).

[44] Nematov SH, Batalov AM, Sultanov AA, Nematov IH. Development of Productive Cotton Cultivars with Increased fibre Quality for Bukhara Region of Uzbekistan. In: Egamberdieva D, Abdurakhmonov I (eds). Cotton Research in Uzbekistan; Asian and Australasian Journal of Plant Science and Biotechnology 7 (Special Issue 2) 2013; 16-18.

[45] Abdurakhmonov IY, Abdukarimov A. Application of association mapping to understanding the genetic diversity of plant germplasm resources. International Journal of Plant Genomics 2008; 574927.

[46] Abdurakhmonov IY, Buriev ZT, Shermatov SE et al. Marker-assisted selection for complex fibre traits in cotton: 5th World Cotton Research Conference, Special session of ICGI, November 7-12, 2011a, Mumbai, India.

[47] Abdurakhmonov IY, Buriev ZT, Shermatov SE, Kushanov FN, Makamov A, Shopulatov U, Turaev O, Norov T, Akhmedov Ch, Mirzaakhmedov M, Abdukarimov A. Utilization of natural diversity in Upland cotton (G. hirsutum) germplasm collection for pyramiding genes via marker-assisted selection program: Presentation in 5th Asian Cotton Research and Development Network conference, February, 2011b, Lahore, Pakistan.

[48] Stich B, Melchinger AE. An Introduction to Association Mapping in Plants. CAB Reviews: Perspectives in Agriculture, Veterinary Science, Nutrition and Natural Resources 2010; 5:1-9. 
[49] Kumpatla SP, Buyyarapu R, Abdurakhmonov IY, Mammadov JA. In: Ibrokhim IY (eds). Genomics-assisted plant breeding in the 21st Century: Technological Advances and Progress. Plant Breeding, Croatia: InTech; 2012. 
